\title{
Novel semi-synthetic Cu (II)-cardamonin complex exerts potent anticancer activity against triple negative breast and pancreatic cancer cells via inhibition of the Akt signaling pathway
}

Md Shahadat Hossan ( $\nabla$ shahadat.hossan@nottingham.ac.uk)

University of Nottingham https://orcid.org/0000-0001-6136-6741

Mohammed Khaled Bin Break

University of Hail

Tracey D. Bradshaw

University of Nottingham

Hilary M. Collins

University of Nottingham

Christophe Wiart

University of Nottingham Malaysia Faculty of Science

Teng-Jin Khoo

University of Nottingham Malaysia Faculty of Science

\section{Research Article}

Keywords: Copper, Cardamonin, Complex, Cytotoxicity, Akt

Posted Date: February 15th, 2021

DOI: https://doi.org/10.21203/rs.3.rs-225415/v1

License: (c) (i) This work is licensed under a Creative Commons Attribution 4.0 International License.

Read Full License 


\section{Abstract}

Triple negative breast cancer (TNBC) and pancreatic cancer are two of the most aggressive types of cancer that lack effective treatments. We have previously reported the semi-synthesis of a novel Cu (II)cardamonin complex (19) that demonstrated potent anti-tumour activity. In this study, we further investigated the bioactivity and mode of action of 19 against MDA-MB-468 and PANC-1 cancer cells in an attempt to discover an effective anticancer agent for TNBC and pancreatic cancer, respectively. Results revealed that 19 abolished formation of MDA-MB-468 and PANC-1 colonies, exerted growth inhibitory activity and inhibited the migration of cancer cells. Further mechanistic studies showed that it induced DNA damage resulting in G2/M-phase arrest and microtubule network disruption. Moreover, there was an increase in ROS production which may have contributed to the observed induction of apoptosis, corroborated by activation of caspase-3/7, cleavage of PARP and downregulation of Mcl-1. Complex 19 also decreased the expression levels of p-Akt and p-4EBP1 in both cell lines, which indicates that the compound exerted its activity, at least in part, via inhibition of the Akt signaling pathway. Furthermore, it decreased the expression of c-Myc in PANC-1 cells only which suggests that it may exert its bioactivity via multiple mechanisms of action pertinent to tumourigenesis. These results demonstrate the potential of 19 as a promising therapeutic agent for TNBC and pancreatic cancer.

\section{Introduction}

Cancer is a major health problem worldwide with 17 million new cases and 9.6 million deaths in 2018 . It is predicted that the number of new cases will increase to 27.5 million cases by the year 2040. Breast cancer is one of the most common types of cancer globally, with 2 million cases reported in 2018. A subgroup of breast cancer known as triple negative breast cancer (TNBC) represents $15-20 \%$ of all breast cancers and is characterised by the lack of oestrogen receptor (ER) and progesterone receptor (PR) expression, in addition to the lack of human epidermal growth factor receptor (HER2) amplification. TNBC is of particular concern as it displays poor prognosis due to its inherently aggressive nature and lack of recognised molecular targets for therapy. Pancreatic cancer is another cancer phenotype that is highly lethal and is a major cause of cancer-related mortality with an overall 5 -year survival of $<7 \%$. The appalling prognosis that is associated with pancreatic cancer is partially due to its aggressive nature and difficult early diagnosis. There is currently a lack of efficient treatments for TNBC and pancreatic cancer, therefore, further research is required in order to develop more effective treatments for these types of cancer [1-5].

Natural products have historically provided an important source of bioactive compounds and have been heavily studied for the purpose of developing effective anticancer agents. Cardamonin is a natural product that belongs to a larger family of compounds known as chalcones and was found to exhibit pronounced cytotoxic activity against a variety of cancer cell lines such as A549, M14, U266, MDA-MB231, HK1 and MCF-7 [6-7]. Moreover, there were many studies that attempted to investigate cardamonin's mechanism of action where it was found to exert its cytotoxic activity via targeting a variety of signaling pathways such as JNK-FOXO3a, Wnt/ $\beta$-catenin and mTOR cascades [8-10]. 
As part of our efforts to discover and develop novel anticancer agents, we synthesised several analogues of cardamonin, and discovered a highly active analogue [11]. This active analogue was the $\mathrm{Cu}$ (II)cardamonin complex (19) (Fig. 1a) which displayed cytotoxic activity against lung cancer and nasopharyngeal carcinoma cell lines. However, to confirm the potential of 19 as a promising anticancer agent, we still have to investigate its cytotoxic activity against other types of cancer and elucidate in detail its mode(s) of action.

Therefore, the main aim of the present study was to examine the cytotoxic activity of 19 against intractable MDA-MB-468 (TNBC) and PANC-1 (pancreatic) cancer cell lines to further explore the potential of 19 as an effective anticancer agent and investigate its mode(s) of action. The study employed a wide range of biological assays to fully assess the anti-tumour activity of 19; ranging from cell viability, apoptosis and migration assays to cell-cycle and Western blot analysis. Herein, we describe the potential of the novel semi-synthetic compound, 19 , as a promising anticancer agent against TNBC and pancreatic cancer, in addition to reporting a detailed description of its mechanisms of action.

\section{Materials And Methods}

\section{Synthesis of 19}

Compound 19 was synthesised and its structure fully characterised as reported in our previous study [11].

\section{Cell culture}

MDA-MB-468 (TNBC) and PANC-1 (pancreatic) cancer cell lines were first obtained from the American Type Tissue Culture Collection (ATCC). Cell cultures were maintained using RPMI 1640 (Sigma-Aldrich UK) supplemented with sodium bicarbonate (2 g/l, Sigma-Aldrich UK), 1\% 200 mM L-glutamine (SigmaAldrich UK) and heat inactivated 10\% foetal bovine serum (FBS) (Sigma-Aldrich UK) under humidified atmosphere containing $5 \% \mathrm{CO}_{2}$ in air at $37^{\circ} \mathrm{C}$.

\section{Cell viability assay}

MTT assay was used to measure cell viability. Cells were seeded in 96 well plates at a density of $3 \times 10^{3}$ cells per well and incubated for $24 \mathrm{~h}$ at $37^{\circ} \mathrm{C}$ prior to treatment. Cells were then treated with 19 at different concentrations and incubated for $72 \mathrm{~h}$. Finally, MTT solution was added to each well and the resulting absorbance was read.

\section{Colony formation assay}

The assay was performed as reported [12].

\section{Migration assay}

Cells were seeded in 6-well plates at a density of $1 \times 10^{6}$ cells per well and allowed to grow until confluency. This was followed by forming a scratch or "wound" in the layer of cells using a sterile $200 \mu \mathrm{l}$ 
pipette tip. The cells were washed with PBS and incubated with 19 in the presence of $10 \%$ FBS for 48 h. Images of the cells were then analysed via ImageJ.

\section{Cell-cycle analysis}

Cell-cycle analysis was performed as reported [11].

\section{$\mathrm{Y}-\mathrm{H} 2 \mathrm{AX}$ detection for DNA damage assessment}

The assay was performed as reported [11].

\section{Confocal microscopy}

Cells were seeded in 8-well $\mu$-slides at a density of $1 \times 10^{4}$ cells per well and incubated overnight. Cells were then treated with 19 for $24 \mathrm{~h}$, fixed with formaldehyde (3.7\% in PBS; 10-15 min) and permeabilised using PBT (PBS + 0.1\% TritonX-100; 2-3 min). Cells were incubated/treated for $1 \mathrm{~h}$ with PBT and $1 \%$ bovine serum albumin (BSA) in order to prevent non-specific protein binding. They were later incubated for $2 \mathrm{~h}$ with monoclonal anti-a-tubulin antibody (Thermo Scientific), washed with PBT and incubated for 1 h with fluorescent secondary antibody (anti-mouse lgG Alexa Fluor 488 F, 1:500 dilution) in the dark. DNA binding dye DRAQ5 (1:3000) was added and cells were incubated for 5 min in the dark. Finally, visualisation of the cells was performed using a Zeiss LSM510 Meta confocal microscope [13].

\section{Annexin V-FITC/propidium iodide (PI) apoptosis assay}

Cells were seeded in 12-well plates at a density of $1.5 \times 10^{5}$ cells per well and incubated overnight. Later, cells were treated with 19 for $24 \mathrm{~h}$ and then trypsinised, collected in FACS tubes and kept on ice for 10 min, washed with PBS and centrifuged to form a pellet. Annexin V-FITC (5 $\mu \mathrm{l})$ and $100 \mu \mathrm{l} 1 \times$ annexin-V buffer were added to the cells followed by incubation for $15 \mathrm{~min}$ at room temperature. PI (10 $\mu \mathrm{l} ; 50 \mu \mathrm{g} / \mathrm{ml}$ in PBS) and $400 \mu$ l annexin-V buffer were later added and the cells were finally placed on ice for $10 \mathrm{~min}$ prior to analysis using a Beckman Coulter FC500 flow cytometer (Indianapolis, USA).

\section{Caspase-Glo 3/7 assay}

The Caspase-Glo 3/7 assay kit (Promega) was used. Cancer cells were seeded at a density of $5 \times 10^{3}$ cells per well and incubated overnight. The cells were then treated with 19 followed by addition of Caspase-Glo 3/7 reagent and incubation for $60 \mathrm{~min}$ prior to reading the results via a multi-label plate reader.

\section{Western blotting analysis}

Cells were seeded in dishes at a density of $1-2 \times 10^{6}$ per dish. After $24 \mathrm{~h}$, cells were treated with 19 for 24 $\mathrm{h}$ and $72 \mathrm{~h}$. Following treatment, cell lysates were prepared, and protein concentrations calculated using the Bradford assay. Protein was subjected to SDS-PAGE for separation and transferred to the nitrocellulose membrane. Whole PARP, cleaved PARP, Mcl-1, Akt, p-Akt, 4EBP1, p-4EBP1, c-Myc and GAPDH primary anitbodies were purchased from Cell Signaling Technologies (Danvers, MA, USA). Anti- 
rabbit and anti-mouse immunoglobulin $\mathrm{G}(\mathrm{IgG})$ horseradish peroxidase-conjugated secondary antibodies were obtained from Dako (Santa Clara, USA).

\section{Reactive oxygen species (ROS) detection}

The ROS-Glo $\mathrm{H}_{2} \mathrm{O}_{2}$ luminometric-based assay (Promega, UK) was used. Cancer cells were seeded at a density of $5 \times 10^{3}$ cells per well and incubated overnight. The cells were then treated with 19 for $24 \mathrm{~h}$. $\mathrm{H}_{2} \mathrm{O}_{2}$ substrate $(25 \mu \mathrm{M})$ was then added to the cells followed by the addition of $100 \mu \mathrm{l}$ ROS-Glo detection solution, and samples were finally incubated for $20 \mathrm{~min}$ at room temperature. Resulting luminescence was detected using a multi-label plate.

\section{Statistical analysis}

Experiments were generally repeated $\geq$ three times and data were expressed as mean \pm SD. Experimental data were analysed via Graphpad Prism. Statistical differences among means were analysed by one-way and two-way ANOVA followed by Dunnett's multiple comparisons tests. Data represent significant values as ${ }^{*} p<0.05, * * p<0.01, * \star * p<0.001$, and $* * \star * p<0.0001$.

\section{Results And Discussion}

\section{Compound 19 inhibited the growth and migration of MDA-MB-468 and PANC-1 cancer cells}

We have previously been able to synthesise a highly active $\mathrm{Cu}$ (II) complex of cardamonin (19) which demonstrated potent cytotoxic activity [11]. In order to further assess the cytotoxic activity of 19, we examined its effect against MDA-MB-468 (TNBC) and PANC-1 (pancreatic) cancer cell lines. The effect of 19 on the cancer cell lines was initially investigated via an MTT cell viability assay and results are summarised in Table 1. Compound 19 demonstrated potent growth inhibitory activity against both MDAMB-468 and PANC-1 cells with $\mathrm{GI}_{50}$ values of $6.14 \mu \mathrm{M}$ and $12.48 \mu \mathrm{M}$, respectively, and it decreased their viability in a dose-dependent manner (Fig. 1b). Moreover, 19 showed an almost 6-fold enhancement in activity against MDA-MB-468 cells relative to its parent compound, cardamonin, while a slight enhancement was observed against PANC-1 cells. This indicates that complexation of cardamonin to $\mathrm{Cu}^{2+}$ was a successful technique to enhance the natural product's bioactivity. Compound 19 was also screened against human normal lung fibroblasts (MRC-5) in order to investigate the compound's selectivity towards cancer cells. Results of the screening showed that 19 exhibited 5.3- and 2.6-fold selectivity towards MDA-MB-468 and PANC- 1 cancer cells relative to non-transformed MRC- 5 cells, respectively. Overall, results showed that 19 was more active towards MDA-MB-468 cells than PANC-1 cells, exhibited superior cytotoxic activity relative to its parent compound, cardamonin, and demonstrated cancer-selectivity.

Table $1 \mathrm{Gl}_{50}$ values of 19 against MDA-MB-468, PANC- 1 and MRC- 5 cells 


\begin{tabular}{|llllll|}
\hline & $\mathrm{GI}_{50}(\mu \mathrm{M})^{\mathrm{a}}$ & & & \multicolumn{3}{c|}{ Selectivity index $(\mathrm{SI})^{\mathrm{b}}$} \\
\hline Compound & MDA-MB-468 & PANC-1 & MRC-5 & MDA-MB-468 & PANC-1 \\
\hline 19 & $6.14 \pm 0.06$ & $12.48 \pm 0.70$ & $32.60 \pm 5.13$ & 5.3 & 2.6 \\
\hline Cardamonin & $34.33 \pm 0.55$ & $19.21 \pm 2.37$ & - & - & - \\
\hline Vincristine sulfate & $0.03 \pm 0.0005$ & $0.48 \pm 0.24$ & $5.58 \pm 0.38$ & 186 & 11.6 \\
\hline
\end{tabular}

${ }^{\text {a }} \mathrm{GI}_{50}$ values are reported as the mean $\left(\mathrm{GI}_{50} \pm \mathrm{SD}\right)$ of at least three independent experiments.

${ }^{\mathrm{b}} \mathrm{SI}=\left(\mathrm{GI}_{50}\right.$ of MRC-5)/(GI 50 of MDA-MB-468 or PANC-1).

To further examine the effect of 19 on the growth of cancer cells, a colony formation assay was conducted. Cultured cancer cells are capable of anchorage-independent growth, possessing the ability to grow in the absence of extracellular matrix and adjacent cells. This property of cancer cells has been linked to tumour cell aggressiveness, in vivo [14]. Anchorage-independent growth may be assessed via a colony formation assay. Colony formation/clonogenic assays also detect the ability of cancer cells to survive a brief challenge with test agent and form progeny colonies, therefore, clonogenic assays were performed to investigate the effect of 19 on the ability of MDA-MB-468 and PANC-1 cells to form colonies (Fig. 1C). Results show that 19 was able to completely prevent the formation of colonies by the cancer cells after $24 \mathrm{~h}$ of treatment. These data indicate that 19 has the ability to kill MDA-MB-468 TNBC and PANC-1 pancreatic tumour-initiating cells and prevent tumour re-colonisation, highlighting its cytotoxic potential.

We subsequently investigated the effect of 19 on cancer cell migration. Cancer cells exhibit the ability to metastasise or migrate from their site of origin to other organs within the body which leads to the spread of cancer. Therefore, wound healing migration assays were performed to examine the effect of 19 on the migration of MDA-MB-468 and PANC-1 cells (Fig. 1d and e). Migration of MDA-MB-468 cells was reduced by $~ 3$-fold and 13-fold, while that of PANC-1 cells was reduced by around 2-fold and 4-fold relative to the control after $48 \mathrm{~h}$ of treatment with 19 at concentrations of $1 \times \mathrm{Gl}_{50}$ and $2 \times \mathrm{Gl}_{50}$, respectively. Therefore, these results indicate that 19 exhibits significant inhibitory effects on the migration of MDA-MB-468 and PANC-1 cells with a more pronounced effect on the former. The migration ability of cancer cells is a crucial factor in invasion and metastasis [15], therefore, these results and those of the clonogenic assay, reflect the potential of 19 to reduce or inhibit cancer cell survival, invasion and metastasis in patients.

Fig. 1 Compound 19 inhibited the growth and migration of cancer cells. a The chemical structure of compound 19. b Representative dose-response profiles demonstrating growth-inhibitory effects of 19 against MDA-MB-468 and PANC-1 cells. c Compound 19 completely inhibited the formation of colonies 
by MDA-MB-468 and PANC- 1 cells after $24 \mathrm{~h}$ of treatment at concentrations of $1 \times \mathrm{GI}_{50}$ and $2 \times \mathrm{GI}_{50}$. d-e Compound 19 significantly inhibited the migration of MDA-MB-468 and PANC-1 cells after $24 \mathrm{~h}$ and $48 \mathrm{~h}$ of treatment at concentrations of $1 \times \mathrm{GI}_{50}$ and $2 \times \mathrm{GI}_{50}$. All assays were repeated at least three times, while bars/points and error bars refer to mean \pm S.D. $* \star \star \star p<0.0001$ vs. control

\section{Compound 19 induced G2/M-phase cell-cycle arrest by triggering DNA damage in MDA-MB-468 and PANC-1 cancer cells}

To further characterise the cytotoxic and growth inhibitory effect of 19 against cancer cells, cell-cycle analysis was conducted in order to investigate the effect of our compound on cell-cycle progression. MDA-MB-468 and PANC- 1 treated with 19 at concentrations of $1 \times \mathrm{GI}_{50}$ and $2 \times \mathrm{Gl}_{50}$ for $24 \mathrm{~h}$ showed a significant increase in the fraction of cells in the G2/M-phase (Fig. 2a). Compound 19 induced the highest accumulation of cells in the $\mathrm{G} 2 / \mathrm{M}$-phase at a concentration of $2 \times \mathrm{Gl}_{50}$ for MDA-MB-468 cells (64.3\% compared to $29.1 \%$ in the untreated cells). However, in PANC-1 cells, the highest accumulation of cells at the $\mathrm{G} 2 / \mathrm{M}$-phase was induced at a concentration of $1 \times \mathrm{GI}_{50}(40.3 \%$ compared to $15.5 \%$ in the untreated cells), while increasing the treatment concentration to $2 \times \mathrm{GI}_{50}$ resulted in significantly increased numbers of events in $\mathrm{G} 2 / \mathrm{M}$ and also pre-G1 phases. These observations indicate that 19 , at $2 \times \mathrm{GI}_{50}$, causes apoptosis in PANC-1 cells.

The induction of G2/M-phase cell-cycle arrest by certain agents often indicates that they also cause DNA damage [16]. Therefore, since compound 19 was able to induce G2/M-phase cell-cycle arrest, we investigated its ability to cause DNA damage. The formation of DNA double-strand breaks (DSB) as a result of DNA damage is accompanied by phosphrylation of histone $\mathrm{H} 2 \mathrm{AX}$ to $\mathrm{Y}-\mathrm{H} 2 \mathrm{AX}$ [17], thus DNA damage may be assessed via quantification of $\mathrm{Y}-\mathrm{H} 2 \mathrm{AX}$. The induction of DNA damage by compound 19 was assessed by quantifying $\mathrm{Y}-\mathrm{H} 2 \mathrm{AX}$-expressing cells post-treatment via flow cytometry. Results showed that $19\left(2 \times \mathrm{Gl}_{50}\right)$ was able to significantly increase the formation of $\mathrm{y}-\mathrm{H} 2 \mathrm{AX}$ by $\sim 8$-fold in both MDA-MB468 and PANC-1 cells relative to the control (Fig. 2b). Moreover, it is interesting to note that 19 also resulted in the formation of $\mathrm{y}-\mathrm{H} 2 \mathrm{AX}$ at higher levels than the positive control, etoposide $(2 \mu \mathrm{M})$. This clearly indicates that the observed cytotoxic activity of 19 involves the induction of DNA damage in the cancer cells.

Fig. 2 Compound 19 induced G2/M-phase cell-cycle arrest by triggering DNA damage in MDA-MB-468 and PANC-1 cancer cells. a Compound 19 induced G2/M-phase cell-cycle arrest in MDA-MB-468 and PANC- 1 cells after $24 \mathrm{~h}$ of treatment at concentrations of $1 \times \mathrm{GI}_{50}$ and $2 \times \mathrm{GI}_{50}$. The figure also shows representative cell-cycle histograms from one of the experiments showing the effect of 19 on cell-cycle progression $\mathbf{b}$ Representative dot-plots illustrating the formation of $\mathrm{Y}-\mathrm{H} 2 \mathrm{AX}$ in MDA-MB-468 and PANC-1 cells after $24 \mathrm{~h}$ of treatment with etoposide and 19 at concentrations of $2 \mu \mathrm{M}$ and $2 \times \mathrm{GI}_{50}$, respectively. All assays were repeated at least three times, while bars and error bars refer to mean \pm S.D. ${ }^{\star} p<0.05$ vs. control, ${ }^{\star \star \star} p<0.001$ vs. control, ${ }^{\star \star \star \star} p<0.0001$ vs. control 
Cell-cycle analysis revealed that 19 caused G2/M-phase arrest in MDA-MB-468 and PANC-1 cancer cells, and this could be indicative of microtubule disruption [18]. Therefore, in order to determine whether 19 affects the microtubule network; MDA-MB-468 and PANC-1 cells were treated for 24 h with 19 at $\mathrm{GI}_{50}$ concentration, stained with DRAQ5 and monoclonal anti a-tubulin antibody, and morphology investigated using confocal microscopy. Confocal microscopy images (Fig. 3) revealed that 19 was able to induce characteristic features in cancer cells that are typical of a microtubule disrupting agent (MDA), such as multinucleation, nuclear fragmentation and microtubule network disruption [18, 19]. Moreover, apoptosisrelated morphological changes were also observed following treatment with 19 , such as membrane blebbing, chromatin condensation and nuclear fragmentation. Therefore, these data suggest that 19 interferes with the cancer cells' microtubule network leading to G2/M-phase cell-cycle arrest which later results in cell death and growth inhibition.

Fig. 3 Compound 19 disrupts the cytoskeletal structure of MDA-MB-468 and PANC-1 cells. a Effect of 19 on MDA-MB-468 cells. b Effect of 19 on PANC-1 cells. Cells were treated with 19 for $24 \mathrm{~h}$ at $\mathrm{GI}_{50}$ concentration. Compound 19 causes nuclear fragmentation (1), multinucleation (2), membrane blebbing (3), microtubule network disruption (4), membrane disruption of nuclei (5), lunate morphology of chromatin and chromatin condensation (6). The experiments were repeated 3 times. Cells were immunostained with an antibody specific for a-Tubulin (green) and counterstained with DRAQ5 (purple).

\section{Compound 19 induced caspasedependent apoptosis and ROS generation in MDA-MB-468 and PANC-1 cancer cells}

Cell-cycle analysis and confocal microscopy suggest that 19 causes apoptosis in MDA-MB-468 and PANC-1 cells. Therefore, to further confirm the induction of apoptosis by 19 in cancer cells, an annexin V/propidium iodide (PI) apoptosis assay was conducted. MDA-MB-468 and PANC-1 cells were treated with 19 for $24 \mathrm{~h}$ at concentrations of $1 \times \mathrm{GI}_{50}$ and $2 \times \mathrm{GI}_{50}$, and apoptotic populations were confirmed by annexin V-FITC/PI dual staining. Results have shown that 19 caused significant dose-dependent early apoptosis (A+/PI-) along with an insignificant number of necrotic cells in both cancer cell lines (Fig. 4a). A small increase in late apoptotic events ( $\mathrm{A}+\mathrm{PI}+)$ was observed in PANC-1 cells, however, MDA-MB-468 cells demonstrated a significant increase in late apoptotic cells after treatment with 19 at $2 \times \mathrm{GI}_{50}$, and this may be a consequence of more rapid apoptosis onset at this concentration. The highest percentage of apoptotic cells at $2 \times \mathrm{GI}_{50}$ was 36\% and 44\% for MDA-MB-468 and PANC-1 cells, respectively (consistent with cell cycle observations).

Apoptosis can be further confirmed by investigating the expression levels of apoptosis-related proteins such as PARP and Mcl-1. PARP is a substrate of caspase-3 which plays an active role in a variety of key biological processes, and its cleavage is indicative of apoptosis [20]. Mcl-1 is an antiapoptotic Bcl-2 family protein. Therefore, MDA-MB-468 and PANC-1 cells were treated with 19 and the expression levels of PARP, cleaved PARP and Mcl-1 were analysed via Western blot. Results of Western blot analyses showed that 19 cleaved PARP and downregulated Mcl-1 in a time-dependent manner which indicates that it induced apoptosis in the cancer cells (Fig. 4b). 
We next explored whether caspases were involved in the induction of apoptosis by 19 , especially crucial executioner caspase 3, whose activation is considered to be a hallmark of apoptosis [21]. Therefore, MDA-MB-468 and PANC-1 cells were treated with 19 and Caspase-Glo 3/7 assays were conducted to investigate the compound's effect on caspase activation. Results showed that 19 was able to induce caspase-3/7 activation in a dose-dependent manner in both MDA-MB-468 and PANC- 1 cells, with more pronounced activity observed in the former (Fig. 4c). This suggested that 19 exerted its cytotoxic activity, at least in part, via the induction of caspase-dependent apoptosis. It is also crucial to note that cleavage of PARP that was observed in the Western blot assay is also indicative of caspase activation which corroborates the caspase assay results. In conclusion; annexin V-FITC/PI assay, caspase assay and Western blot analysis indicate that 19 induces apoptosis in MDA-MB-468 and PANC-1 cells.

After confirming the induction of apoptosis by 19 , we wanted to investigate the possibility that it was triggered via reactive oxygen species (ROS), as ROS are generated by many natural product-derived antitumour agents [22] and may damage DNA and play a role in apoptosis-induction. Therefore, cells were treated with 19, and ROS production was measured using a ROS-Glo $\mathrm{H}_{2} \mathrm{O}_{2}$ luminescence assay.

Compound 19 significantly increased ROS production in MDA-MB-468 and PANC-1 cells by $\sim 7$ - and 10fold, relative to the untreated control, respectively (Fig. 4d). Increasing the treatment concentration from 1 $\times \mathrm{GI}_{50}$ to $2 \times \mathrm{GI}_{50}$ did not result in further significant increases in ROS production in either cell line. So, it can be deduced that the induction of apoptosis by 19 in MDA-MB-468 and PANC-1 cells might be meditated, at least in part, via the production of ROS. However, further experiments are required to confirm the relationship between ROS production and apoptosis induction by 19 in the cancer cells.

Fig. 4 Compound 19 induced caspase-dependent apoptosis and ROS production in MDA-MB-468 and PANC-1 cancer cells. a Results of the annexin V/PI apoptosis assay showed that 19 induced apoptosis in MDA-MB-468 and PANC- 1 cells after $24 \mathrm{~h}$ of treatment at concentrations of $1 \times \mathrm{Gl}_{50}$ and $2 \times \mathrm{GI}_{50}$. Total apoptosis comprises both early and late apoptotic populations. b Western blot analysis of PARP, cleaved PARP and Mcl-1 in MDA-MB-468 and PANC-1 cells. Cells were treated with 19 for $24 \mathrm{~h}$ and $72 \mathrm{~h}$ at a concentration of $2 \times \mathrm{Gl}_{50}$; GAPDH was used as an internal control. c Caspase-3/7 activity of MDA-MB-468 and PANC-1 cells after $24 \mathrm{~h}$ of treatment with 19 at concentrations of $1 \times \mathrm{Gl}_{50}$ and $2 \times \mathrm{GI}_{50}$. $\mathbf{d ~ R O S}$ production in MDA-MB-468 and PANC-1 cells after $24 \mathrm{~h}$ of treatment with 19 at concentrations of $1 \times \mathrm{GI}_{50}$ and $2 \times \mathrm{GI}_{50}$. All assays were repeated at least three times, while bars and error bars refer to mean \pm S.D. ${ }^{\star *} p<0.01$ vs. control, ${ }^{* \star *} p<0.001$ vs. control, $* \star \star \star p<0.0001$ vs. control

\section{Compound 19 exerted its cytotoxic activity in MDA-MB-468 and PANC-1 cells via inhibition of Akt/4EBP1 signaling and downregulation of c-Myc}

Several studies have reported that cardamonin exerted its cytotoxic activity via inhibition of mTOR signaling [23-25]. A further study has shown that cardamonin reduced the expression level of phosphorylated Akt, which is an upstream regulator of mTOR [26]. Akt signaling pathway is normally involved, via the PI3K/Akt/mTOR pathway, in cell proliferation and survival. However, this pathway is abnormally activated in several types of breast cancer, including TNBC, which contributes to the disease's 
aggressiveness [27]. Akt activation was also often observed in pancreatic cancer, whereby it is considered as a "master regulator" of cancer cell metastasis [28].

Therefore, we reasoned that the observed cytotoxic activity of 19 , an analogue of cardamonin, against MDA-MB-468 and PANC-1 cells might have occurred via a similar mechanism to that of cardamonin. Western blot analysis showed that 19 decreased the expression of phosphorylated Akt (p-Akt) in a timedependent manner in both MDA-MB-468 and PANC-1 cells (Fig. 5a). Moreover, results have shown that 19 also downregulated the expression levels of phosphorylated 4EBP1 ( $\mathrm{p}-4 \mathrm{EBP} 1)$, and this protein is the first downstream substrate of mTOR. Therefore, these results suggest that 19 exerted its cytotoxic activity in MDA-MB-468 and PANC-1 cells, at least in part, via inhibition of the Akt signaling pathway. It can be further deduced that 19 is involved in the modulation of the mTOR signaling pathway, as our data clearly show that it downregulated p-Akt and p-4EBP1 which are upstream and downstream components of mTOR, respectively.

TNBC and pancreatic cancer are also characterised by an overexpression of the oncoprotein c-Myc which contributes to the growth and proliferation of cancer cells [29-30]. Therefore, we wanted to investigate if the cytotoxic activity of 19 involved suppression of c-Myc expression. Western blot analysis showed that 19 downregulated the expression level of c-Myc in PANC-1 cells (Fig. 5b), however, no change was observed in MDA-MB-468 cells (result not shown). These results are consistent with a c-Myc's role in promotion of pancreatic malignancy and pancreatic cancer cell proliferation and migration and concur with findings of previous studies which reported that inhibition of c-Myc affects the progression of pancreatic cancer cells [31-33]. This suggests that 19 may perturb multiple signaling nodes pertinent to tumourigenesis and can exert its cytotoxic activity in PANC-1 cells via a different/additional mechanism than that of MDA-MB-468.

\section{Conclusion}

In summary, the present study involves detailed assessment of the cytotoxic activity of novel semisynthetic compound 19, investigating its activity and molecular mechanisms of action in MDA-MB-468 and PANC-1 cell lines. Compound $\mathbf{1 9}$ demonstrated significant cytotoxic activity against the cancer cell lines and showed higher bioactivity than cardamonin which reflects the positive effect of complexation on bioactivity in this case. Furthermore, 19 inhibited cancer cell colony formation and migration ability. After establishing the efficacy of $\mathbf{1 9}$, we next explored its mode(s) of action, whereby it was found that our compound increased ROS production which may have resulted in the observed induction of DNA damage and subsequent G2/M-phase cell-cycle arrest. It was also found that 19 induced caspasedependent apoptosis in the cancer cells and it could be due to the production of ROS, while further mechanistic studies showed that it inhibited Akt signaling. Fig. 6 summarises the proposed signaling pathways triggered by compound 19 in the cancer cells. Taken together, this study further highlighted the anticancer potential of $\mathbf{1 9}$, corroborating the findings of our previous study [11], and has provided a better understanding of the mode(s) of action of our compound. To the best of our knowledge, compound 19 is the first synthetic cardamonin analogue that has demonstrated promising anti-tumour activity, and the 
only analogue whose mechanism of action has been studied in such detail, as presented in this study. It is expected that such groundwork will guide future in vivo studies on 19 in order to further develop the compound as an effective anticancer drug for TNBC and pancreatic cancer.

\section{Declarations}

\section{Funding}

This research did not receive any specific grant from funding agencies in the public, commercial, or notfor-profit sectors.

\section{Conflicts of interest}

The authors declare that they have no competing interests.

\section{Availability of data and material}

The data generated and/or analyzed during the current study are available from the corresponding author on reasonable request.

\section{Code availability}

Not applicable

\section{Author contributions}

Md Shahadat Hossan was involved in the conceptualisation of the study and writing of the manuscript in addition to conducting all the biological assays/experiments and analysing the resulting data. Mohammed Khaled Bin Break synthesised the Cu(II)-cardamonin complex used in the study, analysed the biological data and wrote the manuscript. Tracey $\mathrm{D}$. Bradshaw supervised the study and was involved in its conceptualisation, in addition to reviewing and editing the manuscript. Hilary M. Collins provided assistance with regards to the use of confocal microscopy in addition to reviewing and editing the manuscript. Christophe Wiart and Teng-Jin Khoo reviewed the manuscript and provided feedback. All authors have approved the final article.

\section{Ethics approval}

Not applicable

\section{Consent to participate}

Not applicable

\section{Consent for publication}


Not applicable

\section{References}

[1] World Health Organization (2018) Cancer. https://www.who.int/news-room/fact-sheets/detail/cancer. Accessed 29 March 2020

[2] Cancer Research UK (2018) Worldwide cancer incidence statistics.

https://www.cancerresearchuk.org/health-professional/cancer-statistics/worldwide-cancer/incidence. Accessed 29 March 2020

[3] Bianchini G, Balko JM, Mayer IA, Sanders ME, Gianni L (2016) Triple-negative breast cancer: challenges and opportunities of a heterogeneous disease. Nat Rev Clin Oncol 13:674-690. https://doi.org/10.1038/nrclinonc.2016.66

[4] Kleeff J, Korc M, Apte M, La Vecchia C, Johnson CD, Biankin A V, Neale RE, Tempero M, Tuveson DA, Hruban RH, Neoptolemos JP (2016) Pancreatic cancer. Nat Rev Dis Prim 2:16022.

https://doi.org/10.1038/nrdp.2016.22

[5] Grant C V, Carver CM, Hastings SD, Ramachandran K, Muniswamy M, Risinger AL, Beutler JA, Mooberry SL (2019) Triple-negative breast cancer cell line sensitivity to englerin A identifies a new, targetable subtype. Breast Cancer Res Treat 177:345-355. https://doi.org/10.1007/s10549-019-05324-7

[6] Gonçalves LM, Valente IM, Rodrigues JA (2014) An overview on cardamonin. J Med Food 17:633640. https://doi.org/10.1089/jmf.2013.0061

[7] Break MKB, Chiang M, Wiart C, Chin CF, Khoo A, Khoo TJ (2020) Cytotoxic activity of Boesenbergia rotunda extracts against nasopharyngeal carcinoma cells (HK1). Cardamonin, a Boesenbergia rotunda constituent, inhibits growth and migration of HK1 cells by inducing caspase-dependent apoptosis and G2/M-phase arrest. Nutr Cancer 1-11. https://doi.org/10.1080/01635581.2020.1751217

[8]. Shrivastava S, Jeengar MK, Thummuri D, Koval A, Katanaev VL, Marepally S, Naidu VGM (2017) Cardamonin, a chalcone, inhibits human triple negative breast cancer cell invasiveness by downregulation of $\mathrm{Wnt} / \beta$-catenin signaling cascades and reversal of epithelial-mesenchymal transition. BioFactors 43:152-169. https://doi.org/10.1002/biof.1315

[9] Nawaz J, Rasul A, Shah MA, Hussain G, Riaz A, Sarfraz I, Zafar S, Adnan M, Khan AH, Selamoglu Z (2020) Cardamonin: A new player to fight cancer via multiple cancer signaling pathways. Life Sci 250. https://doi.org/10.1016/j.lfs.2020.117591

[10] Kong W, Li C, Qi Q, Shen J, Chang K (2020) Cardamonin induces G2/M arrest and apoptosis via activation of the JNK-FOXO3a pathway in breast cancer cells. Cell Biol Int 44:177-188. https://doi.org/10.1002/cbin.11217 
[11] Break MKB, Hossan MS, Khoo Y, Qazzaz ME, Al-Hayali MZK, Chow SC, Wiart C, Bradshaw TD, Collins $\mathrm{H}$, Khoo T-J (2018) Discovery of a highly active anticancer analogue of cardamonin that acts as an inducer of caspase-dependent apoptosis and modulator of the mTOR pathway. Fitoterapia 125:161-173. https://doi.org/https://doi.org/10.1016/j.fitote.2018.01.006

[12] Qazzaz ME, Raja VJ, Lim K-H, Kam T-S, Lee JB, Gershkovich P, Bradshaw TD (2016) In vitro anticancer properties and biological evaluation of novel natural alkaloid jerantinine B. Cancer Lett 370:185-197. https://doi.org/https://doi.org/10.1016/j.canlet.2015.10.013

[13] Collins HM, Abdelghany MK, Messmer M, Yue B, Deeves SE, Kindle KB, Mantelingu K, Aslam A, Winkler GS, Kundu TK, Heery DM (2013) Differential effects of garcinol and curcumin on histone and p53 modifications in tumour cells. BMC Cancer 13:37. https://doi.org/10.1186/1471-2407-13-37

[14] Mori S, Chang JT, Andrechek ER, Matsumura N, Baba T, Yao G, Kim JW, Gatza M, Murphy S, Nevins JR (2009) Anchorage-independent cell growth signature identifies tumors with metastatic potential. Oncogene 28:2796-2805. https://doi.org/10.1038/onc.2009.139

[15] Nandakumar N, Muthuraman S, Gopinath P, Nithya P, Gopas J, Kumar RS (2017) Synthesis of coumaperine derivatives: Their NF-KB inhibitory effect, inhibition of cell migration and their cytotoxic activity. Eur J Med Chem 125:1076-1087. https://doi.org/https://doi.org/10.1016/j.ejmech.2016.10.047

[16] Wu C-F, Efferth T (2015) Miltirone Induces G2/M Cell Cycle Arrest and Apoptosis in CCRF-CEM Acute Lymphoblastic Leukemia Cells. J Nat Prod 78:1339-1347.

https://doi.org/10.1021/acs.jnatprod.5b00158

[17] Sone K, Piao L, Nakakido M, Ueda K, Jenuwein T, Nakamura Y, Hamamoto R (2014) Critical role of lysine 134 methylation on histone H2AX for $\mathrm{Y}-\mathrm{H} 2 \mathrm{AX}$ production and DNA repair. Nat Commun 5:5691. https://doi.org/10.1038/ncomms6691

[18] Hossan MS, Chan Z-Y, Collins HM, Shipton FN, Butler MS, Rahmatullah M, Lee JB, Gershkovich P, Kagan L, Khoo T-J, Wiart C, Bradshaw TD (2019) Cardiac glycoside cerberin exerts anticancer activity through PI3K/AKT/mTOR signal transduction inhibition. Cancer Lett 453:57-73.

https://doi.org/https://doi.org/10.1016/j.canlet.2019.03.034

[19] Smedley CJ, Stanley PA, Qazzaz ME, Prota AE, Olieric N, Collins H, Eastman H, Barrow AS, Lim K-H, Kam T-S, Smith BJ, Duivenvoorden HM, Parker BS, Bradshaw TD, Steinmetz MO, Moses JE (2018) Sustainable Syntheses of (-)-Jerantinines A \& E and Structural Characterisation of the JerantinineTubulin Complex at the Colchicine Binding Site. Sci Rep 8:10617. https://doi.org/10.1038/s41598-01828880-2

[20] Vizetto-Duarte C, Custódio L, Gangadhar KN, Lago JHG, Dias C, Matos AM, Neng N, Nogueira JMF, Barreira L, Albericio F, Rauter AP, Varela J (2016) Isololiolide, a carotenoid metabolite isolated from the brown alga Cystoseira tamariscifolia, is cytotoxic and able to induce apoptosis in hepatocarcinoma cells 
through caspase-3 activation, decreased Bcl-2 levels, increased p53 expression and PARP cleava. Phytomedicine 23:550-557. https://doi.org/https://doi.org/10.1016/j.phymed.2016.02.008

[21] Gong L, Tang Y, An R, Lin M, Chen L, Du J (2017) RTN1-C mediates cerebral ischemia/reperfusion injury via ER stress and mitochondria-associated apoptosis pathways. Cell Death \& Dis 8:e3080

[22] Tsang WP, Chau SPY, Kong SK, Fung KP, Kwok TT (2003) Reactive oxygen species mediate doxorubicin induced p53-independent apoptosis. Life Sci 73:2047-2058.

https://doi.org/https://doi.org/10.1016/S0024-3205(03)00566-6

[23] Tang Y, Fang Q, Shi D, Niu P, Chen Y, Deng J (2014) mTOR inhibition of cardamonin on antiproliferation of A549 cells is involved in a FKBP12 independent fashion. Life Sci 99:44-51. https://doi.org/https://doi.org/10.1016/j.Ifs.2014.01.066

[24] Niu P, Li J, Chen H, Zhu Y, Zhou J, Shi D (2020) Anti-proliferative effect of cardamonin on mTOR inhibitor-resistant cancer cells. Mol Med Rep 21:1399-1407. https://doi.org/10.3892/mmr.2019.10898

[25] Xue Z-G, Niu P-G, Shi D-H, Liu Y, Deng J, Chen Y-Y (2015) Cardamonin Inhibits Angiogenesis by mTOR Downregulation in SKOV3 Cells. Planta Med 82:70-75. https://doi.org/10.1055/s-0035-1557901

[26] Zhou X, Zhou R, Li Q, Jie X, Hong J, Zong Y, Dong X, Zhang S, Li Z, Wu G (2019) Cardamonin inhibits the proliferation and metastasis of non-small-cell lung cancer cells by suppressing the PI3K/Akt/mTOR pathway. Anticancer Drugs 30:241-250. https://doi.org/10.1097/CAD.0000000000000709

[27] Costa RLB, Han HS, Gradishar WJ (2018) Targeting the PI3K/AKT/mTOR pathway in triple-negative breast cancer: a review. Breast Cancer Res Treat 169:397-406. https://doi.org/10.1007/s10549-0184697-y

[28] Wei R, Cortez Penso NE, Hackman RM, Wang Y, Mackenzie GG (2019) Epigallocatechin-3-Gallate (EGCG) Suppresses Pancreatic Cancer Cell Growth, Invasion, and Migration partly through the Inhibition of Akt Pathway and Epithelial-Mesenchymal Transition: Enhanced Efficacy When Combined with Gemcitabine. Nutr. 11:1856. https://doi.org/10.3390/nu11081856

[29] Hu M-H, Wu T-Y, Huang Q, Jin G (2019) New substituted quinoxalines inhibit triple-negative breast cancer by specifically downregulating the c-MYC transcription. Nucleic Acids Res 47:10529-10542. https://doi.org/10.1093/nar/gkz835

[30] Skoudy A, Hernández-Muñoz I, Navarro P (2011) Pancreatic Ductal Adenocarcinoma and Transcription Factors: Role of c-Myc. J Gastrointest Cancer 42:76-84. https://doi.org/10.1007/s12029011-9258-0

[31] Buchholz M, Schatz A, Wagner M, Michl P, Linhart T, Adler G, Gress TM, Ellenrieder V (2006) Overexpression of c-myc in pancreatic cancer caused by ectopic activation of NFATc1 and the Ca2+/calcineurin signaling pathway. EMBO J 25:3714-3724. https://doi.org/10.1038/sj.emboj.7601246 
[32] Yu Q, Zhou X, Xia Q, Shen J, Yan J, Zhu J, Li X, Shu M (2016) Long non-coding RNA CCAT1 that can be activated by c-Myc promotes pancreatic cancer cell proliferation and migration. Am J Transl Res 8:5444-5454.

[33] Sodir NM, Kortlever RM, Barthet VJA, Campos T, Pellegrinet L, Kupczak S, Anastasiou P, Brown Swigart L, Soucek L, Arends MJ, Littlewood TD, Evan GI (2020) Myc instructs and maintains pancreatic adenocarcinoma phenotype. Cancer Discov CD-19-0435. https://doi.org/10.1158/2159-8290.CD-19-0435

\section{Figures}


$\mathbf{a}$

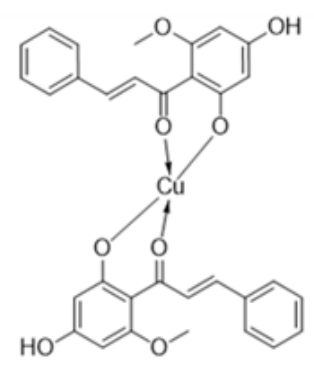

$\mathbf{c}$

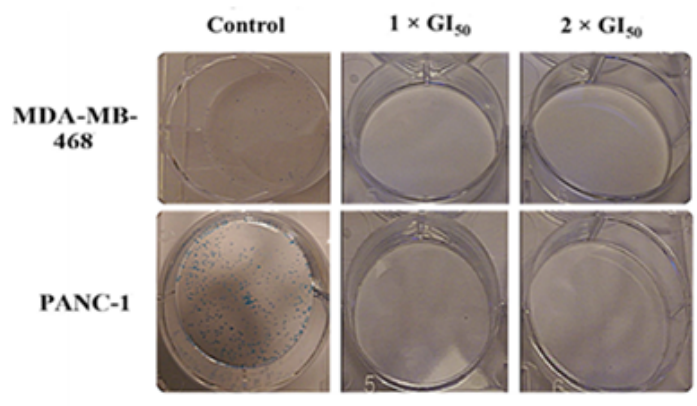

\section{d}
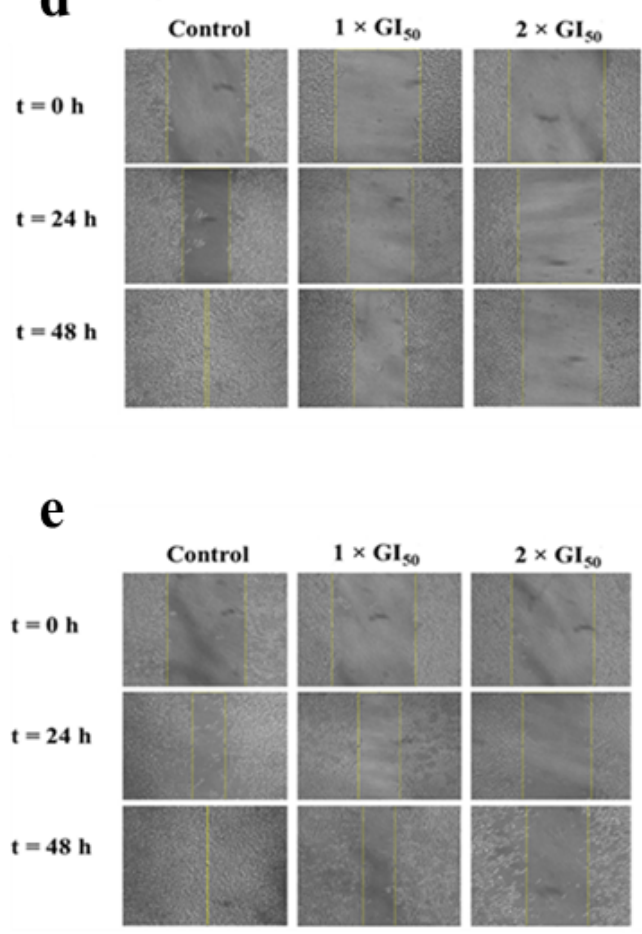

b
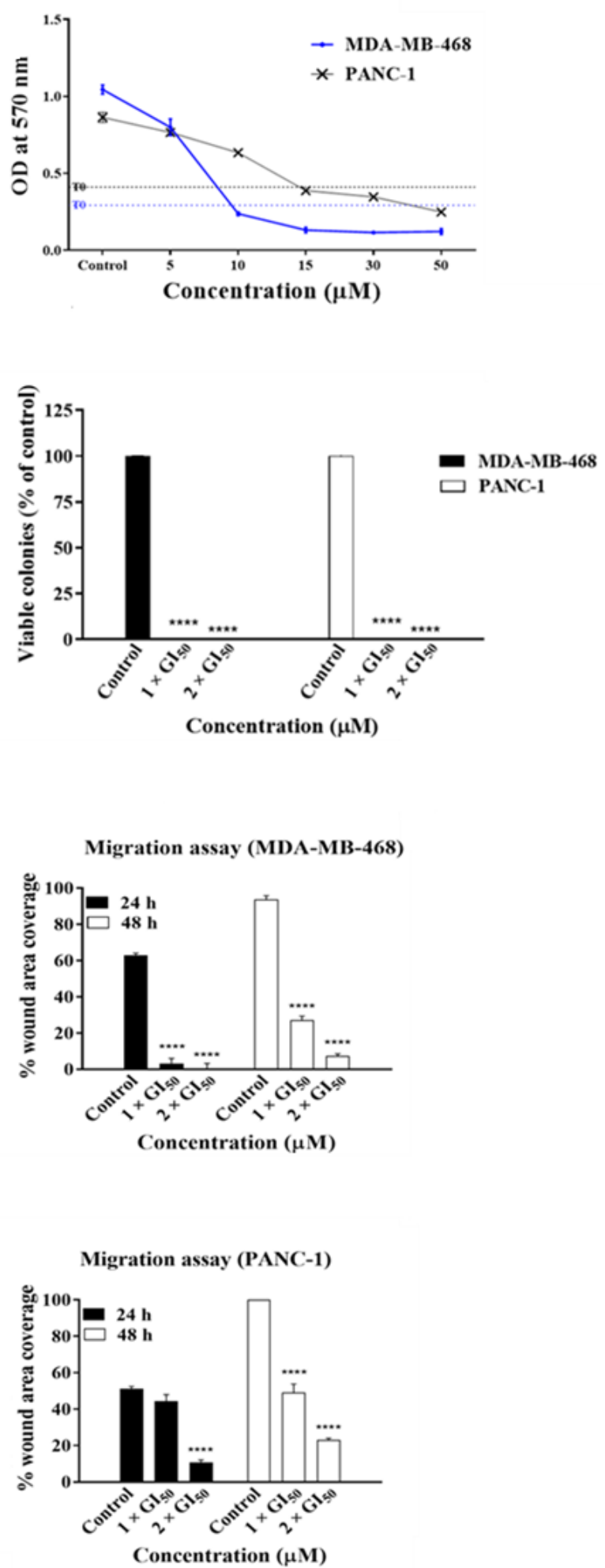

\section{Figure 1}

Compound 19 inhibited the growth and migration of cancer cells. a The chemical structure of compound 19. b Representative dose-response profiles demonstrating growth-inhibitory effects of 19 against MDAMB-468 and PANC-1 cells. c Compound 19 completely inhibited the formation of colonies by MDA-MB468 and PANC- 1 cells after $24 \mathrm{~h}$ of treatment at concentrations of $1 \times \mathrm{GI} 50$ and $2 \times \mathrm{GI} 50$. d-e Compound 19 significantly inhibited the migration of MDA-MB-468 and PANC- 1 cells after $24 \mathrm{~h}$ and $48 \mathrm{~h}$ of treatment 
at concentrations of $1 \times \mathrm{GI} 50$ and $2 \times \mathrm{GI} 50$. All assays were repeated at least three times, while bars/points and error bars refer to mean \pm S.D. ${ }^{*} * \star * p<0.0001$ vs. control

a

Control
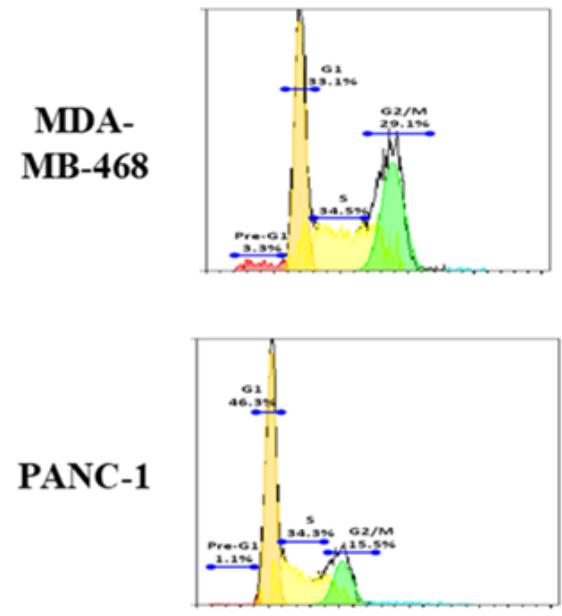

$1 \times \mathrm{GI}_{50}$
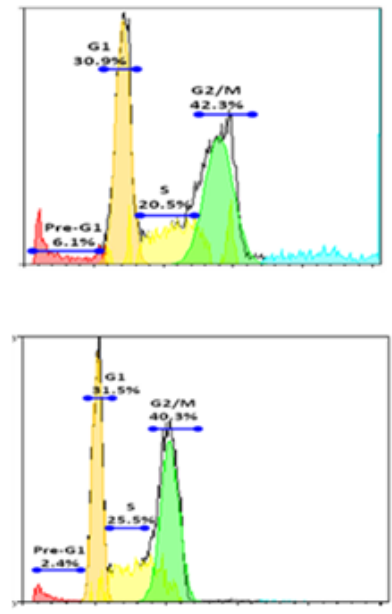

$2 \times \mathbf{G I}_{50}$
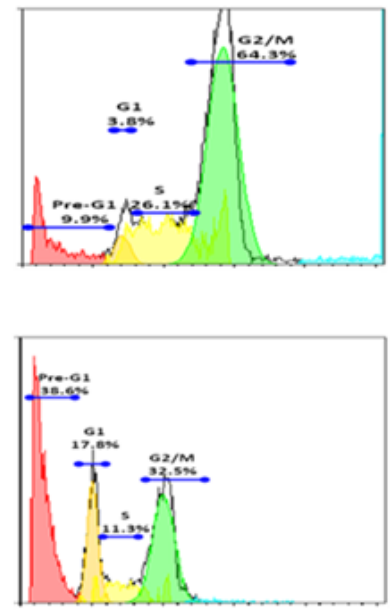

Effect of 19 on MDA-MB-468 cell cycle

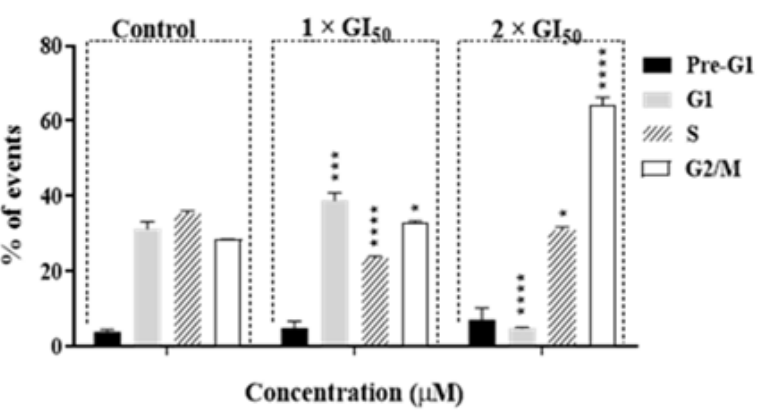

b

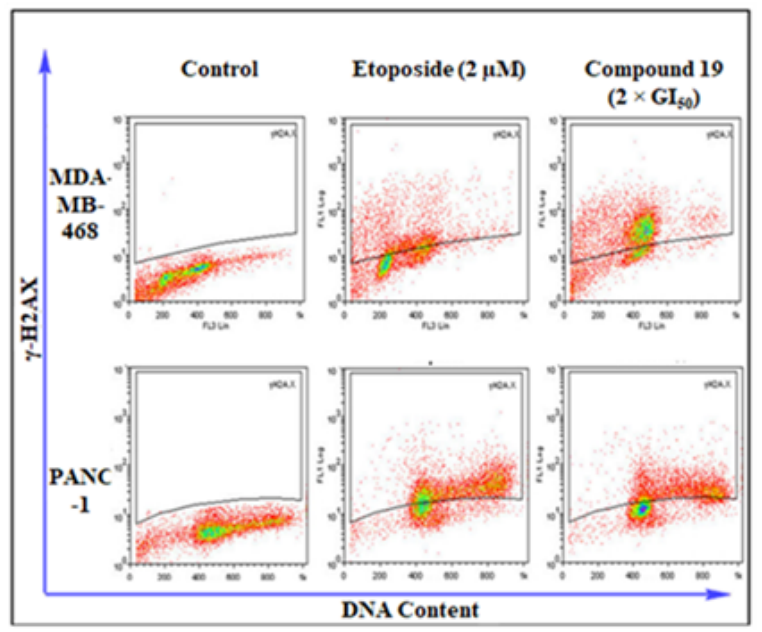

Effect of 19 on PANC-1 cell cycle
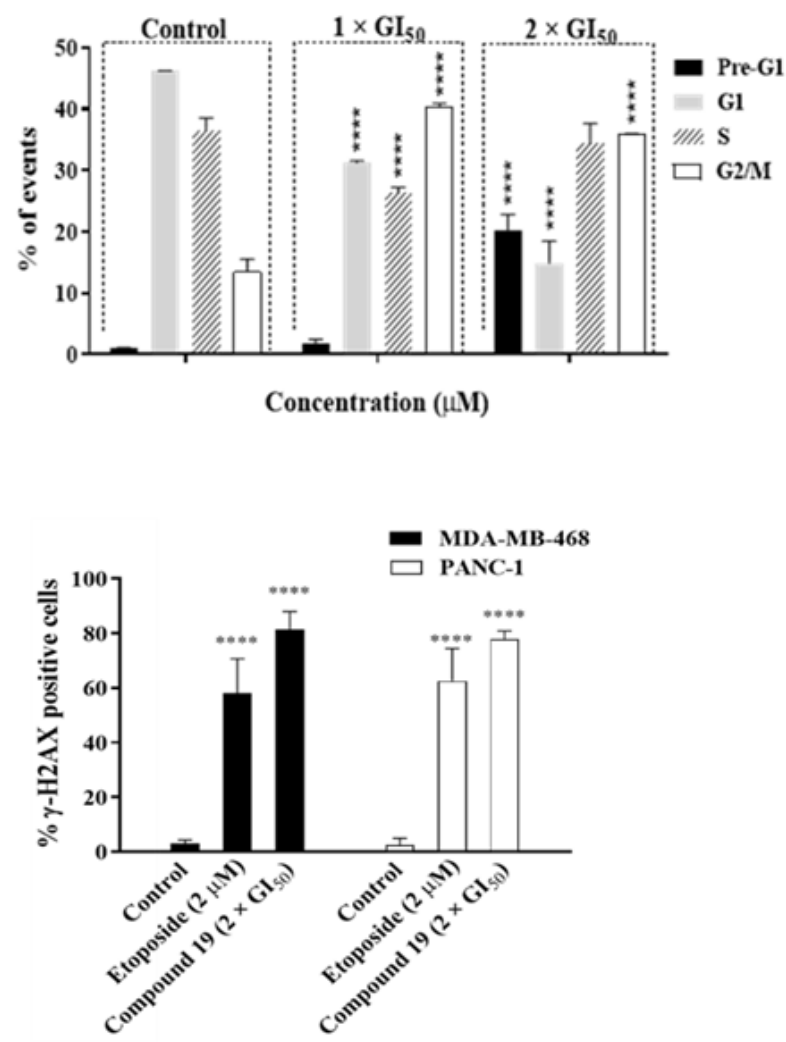

Figure 2

Compound 19 induced G2/M-phase cell-cycle arrest by triggering DNA damage in MDA-MB-468 and PANC-1 cancer cells. a Compound 19 induced G2/M-phase cell-cycle arrest in MDA-MB-468 and PANC-1 cells after $24 \mathrm{~h}$ of treatment at concentrations of $1 \times \mathrm{GI} 50$ and $2 \times \mathrm{GI} 50$. The figure also shows 
representative cell-cycle histograms from one of the experiments showing the effect of 19 on cell-cycle progression $b$ Representative dot-plots illustrating the formation of $\mathrm{y}-\mathrm{H} 2 \mathrm{AX}$ in MDA-MB-468 and PANC-1 cells after $24 \mathrm{~h}$ of treatment with etoposide and 19 at concentrations of $2 \mu \mathrm{M}$ and $2 \times \mathrm{GI} 50$, respectively. All assays were repeated at least three times, while bars and error bars refer to mean \pm S.D. ${ }^{*} p<0.05$ vs. control, $* * * p<0.001$ vs. control, $* * * k p<0.0001$ vs. control

$\mathbf{a}$

Control

Compound

19
MDA-MB-468
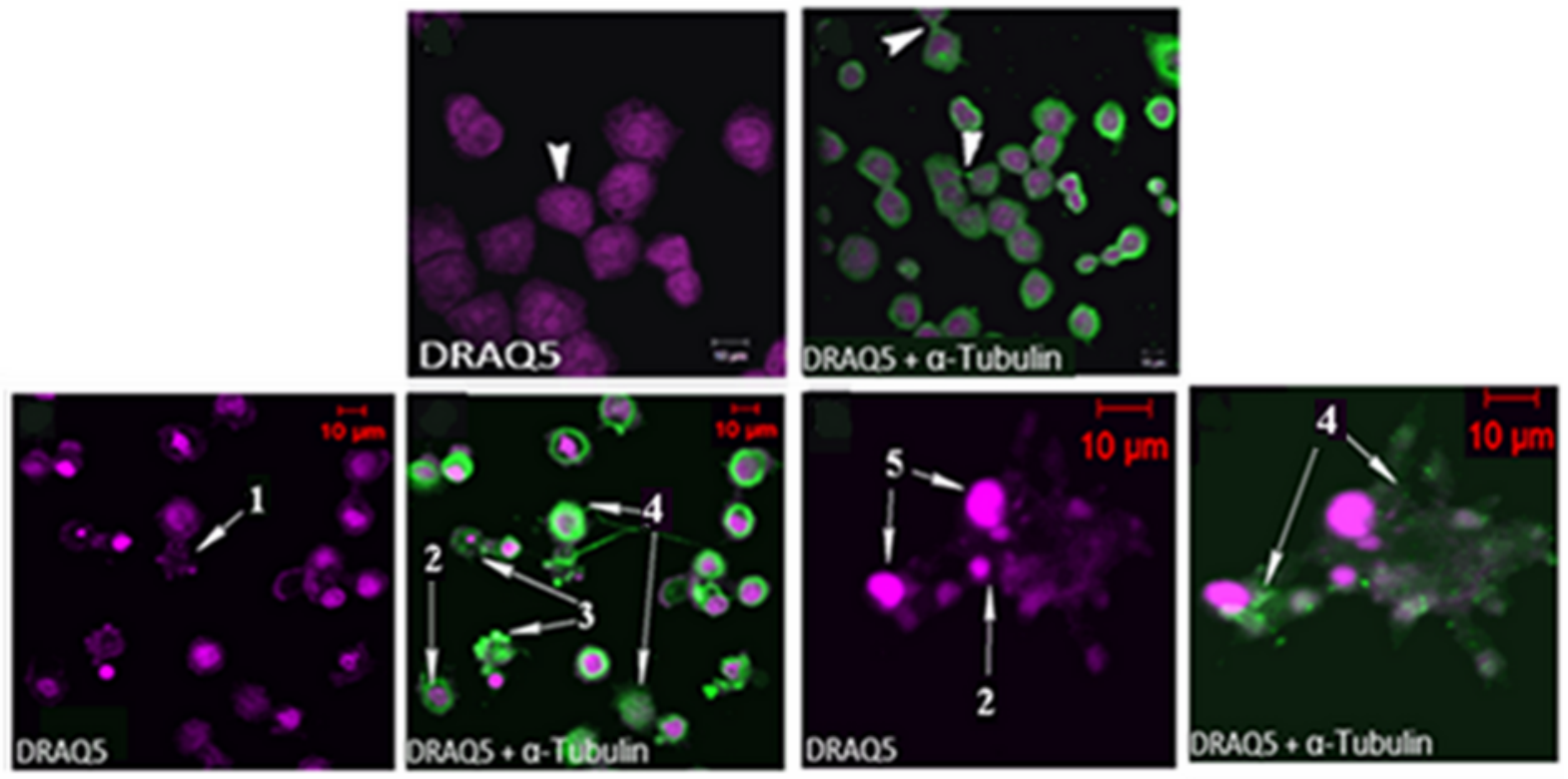

b

PANC-1

Control

Compound 19
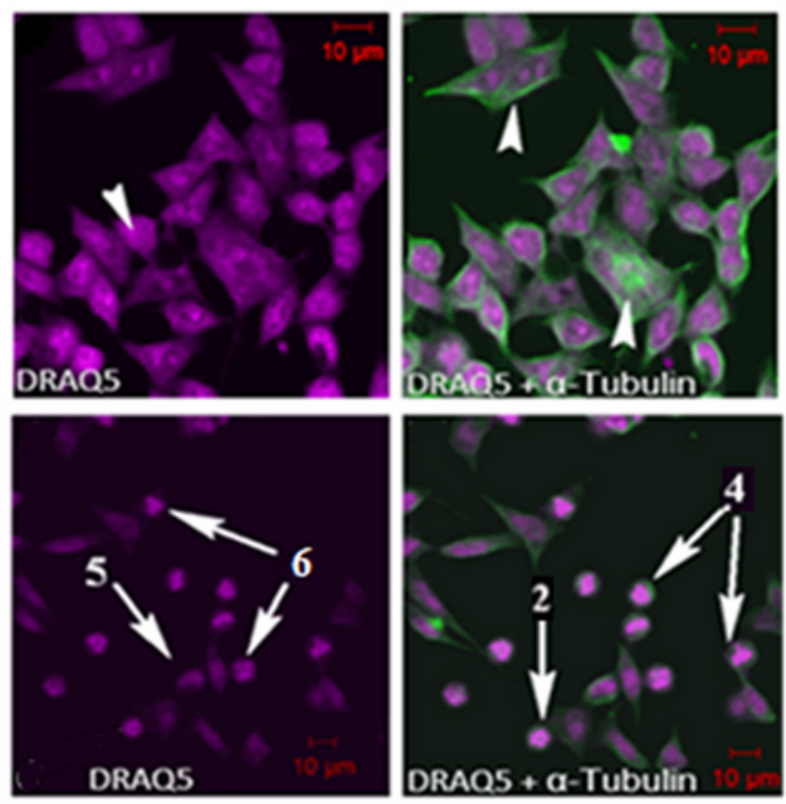

Figure 3 
Compound 19 disrupts the cytoskeletal structure of MDA-MB-468 and PANC-1 cells. a Effect of 19 on MDA-MB-468 cells. b Effect of 19 on PANC- 1 cells. Cells were treated with 19 for $24 \mathrm{~h}$ at GI50 concentration. Compound 19 causes nuclear fragmentation (1), multinucleation (2), membrane blebbing (3), microtubule network disruption (4), membrane disruption of nuclei (5), lunate morphology of chromatin and chromatin condensation (6). The experiments were repeated 3 times. Cells were immunostained with an antibody specific for a-Tubulin (green) and counterstained with DRAQ5 (purple).

a

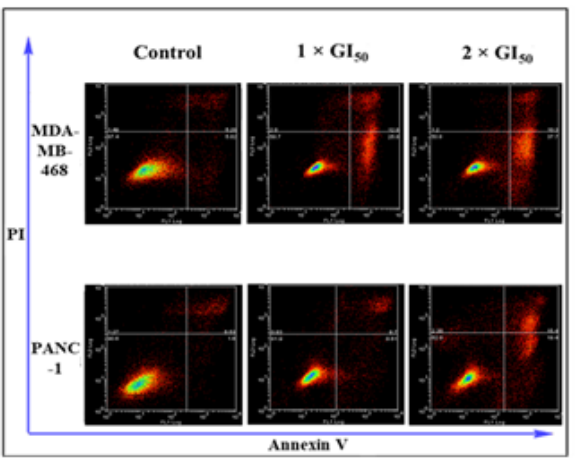

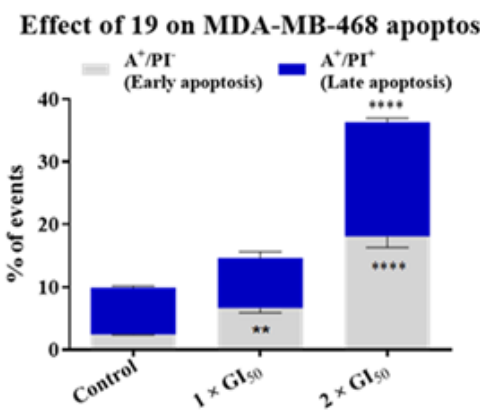

Concentration $(\mu \mathrm{M})$

b

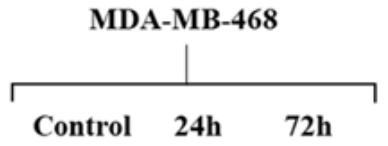

Whole PARP

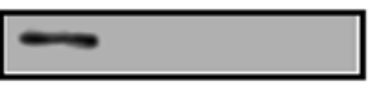

Cleaved PARP

Mcl-1

GAPDH
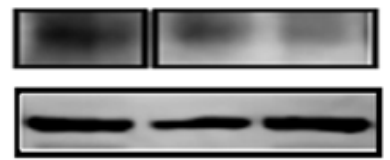

c

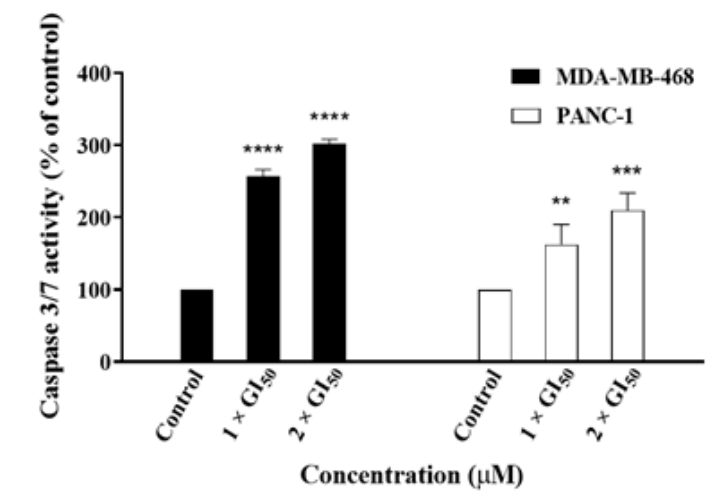

Effect of 19 on PANC-1 apoptosis

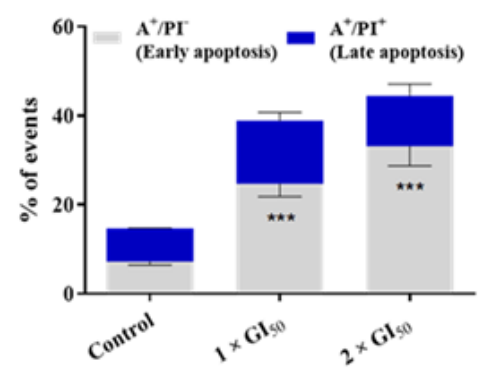

Concentration $(\mu \mathrm{M})$
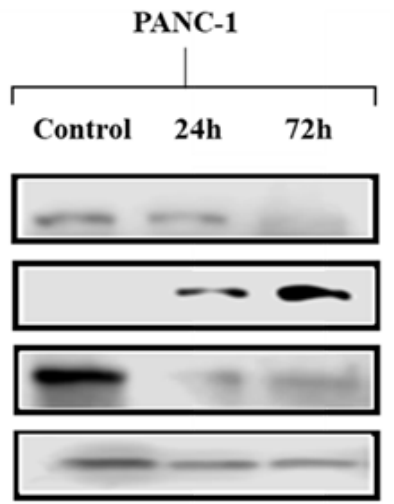

d

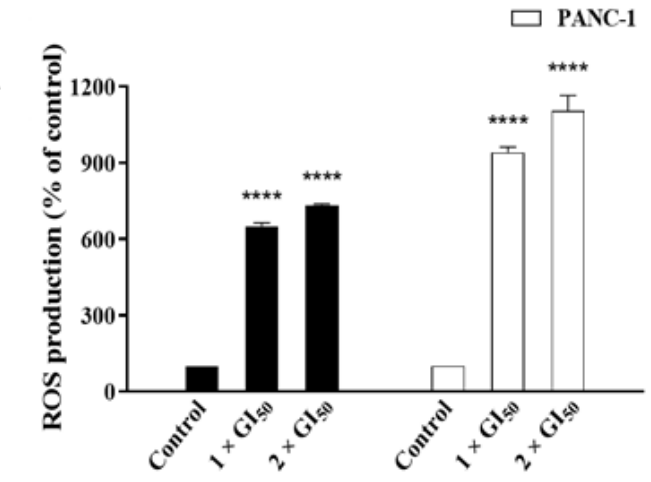

Concentration $(\mu \mathrm{M})$

Figure 4 
Compound 19 induced caspase-dependent apoptosis and ROS production in MDA-MB-468 and PANC-1 cancer cells. a Results of the annexin V/PI apoptosis assay showed that 19 induced apoptosis in MDAMB-468 and PANC- 1 cells after $24 \mathrm{~h}$ of treatment at concentrations of $1 \times \mathrm{GI} 50$ and $2 \times \mathrm{GI} 50$. Total apoptosis comprises both early and late apoptotic populations. b Western blot analysis of PARP, cleaved PARP and Mcl-1 in MDA-MB-468 and PANC-1 cells. Cells were treated with 19 for $24 \mathrm{~h}$ and $72 \mathrm{~h}$ at a concentration of $2 \times$ GI50; GAPDH was used as an internal control. c Caspase-3/7 activity of MDA-MB468 and PANC- 1 cells after $24 \mathrm{~h}$ of treatment with 19 at concentrations of $1 \times \mathrm{GI} 50$ and $2 \times \mathrm{GI} 50$. d ROS production in MDA-MB-468 and PANC-1 cells after $24 \mathrm{~h}$ of treatment with 19 at concentrations of $1 \times$ $\mathrm{GI} 50$ and $2 \times \mathrm{GI} 50$. All assays were repeated at least three times, while bars and error bars refer to mean \pm S.D. ${ }^{\star \star} p<0.01$ vs. control, ${ }^{\star \star *} p<0.001$ vs. control, ${ }^{\star \star *} \times p<0.0001$ vs. control

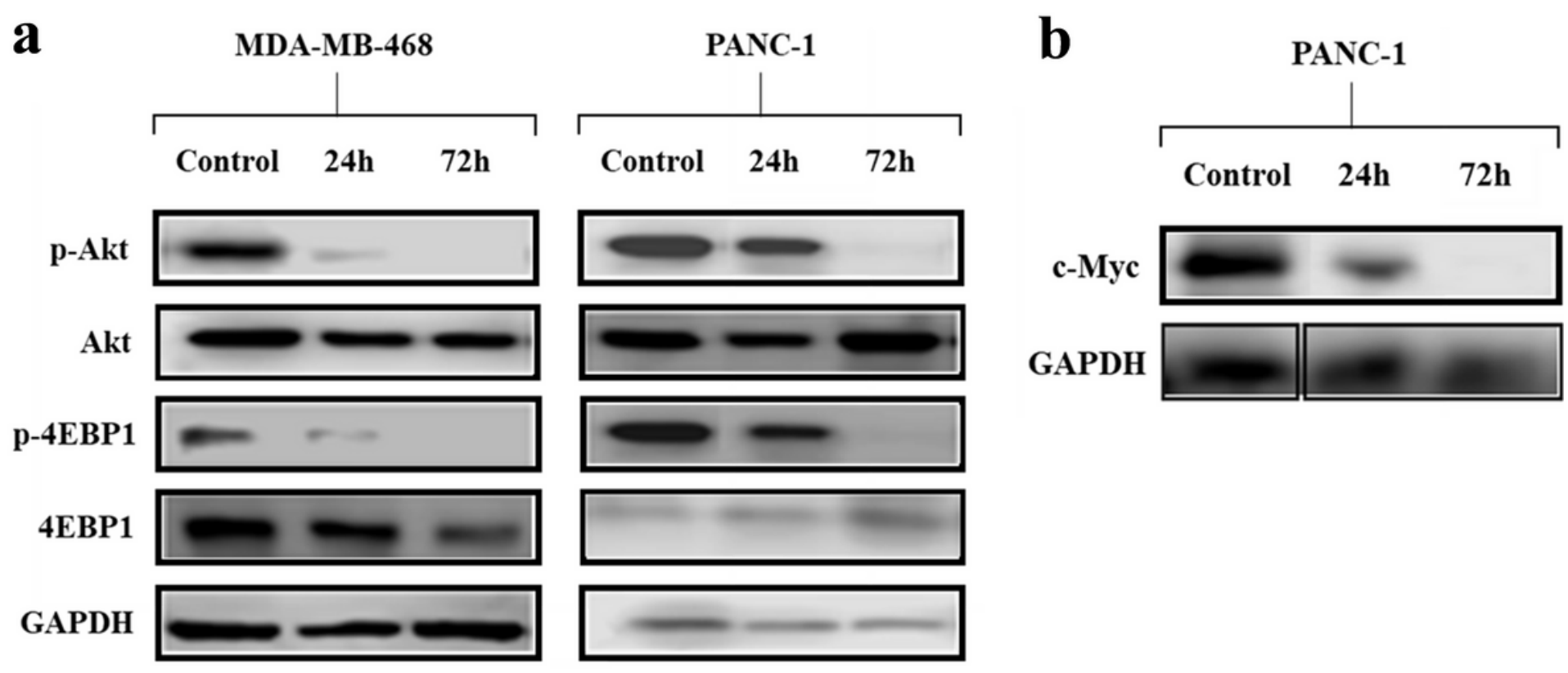

Figure 5

Compound 19 inhibited Akt signaling and decreased the expression of c-Myc in PANC-1 cells. a Western blot analysis of p-Akt, Akt, p-4EBP1, 4EBP1 in MDA-MB-468 and PANC-1 cells. b Western blot analysis of c-Myc in PANC-1 cells only. Cells were treated with 19 for $24 \mathrm{~h}$ and $72 \mathrm{~h}$ at a concentration of $2 \times \mathrm{GI} 50$. GAPDH was used as an internal control. All assays were repeated at least three times. 


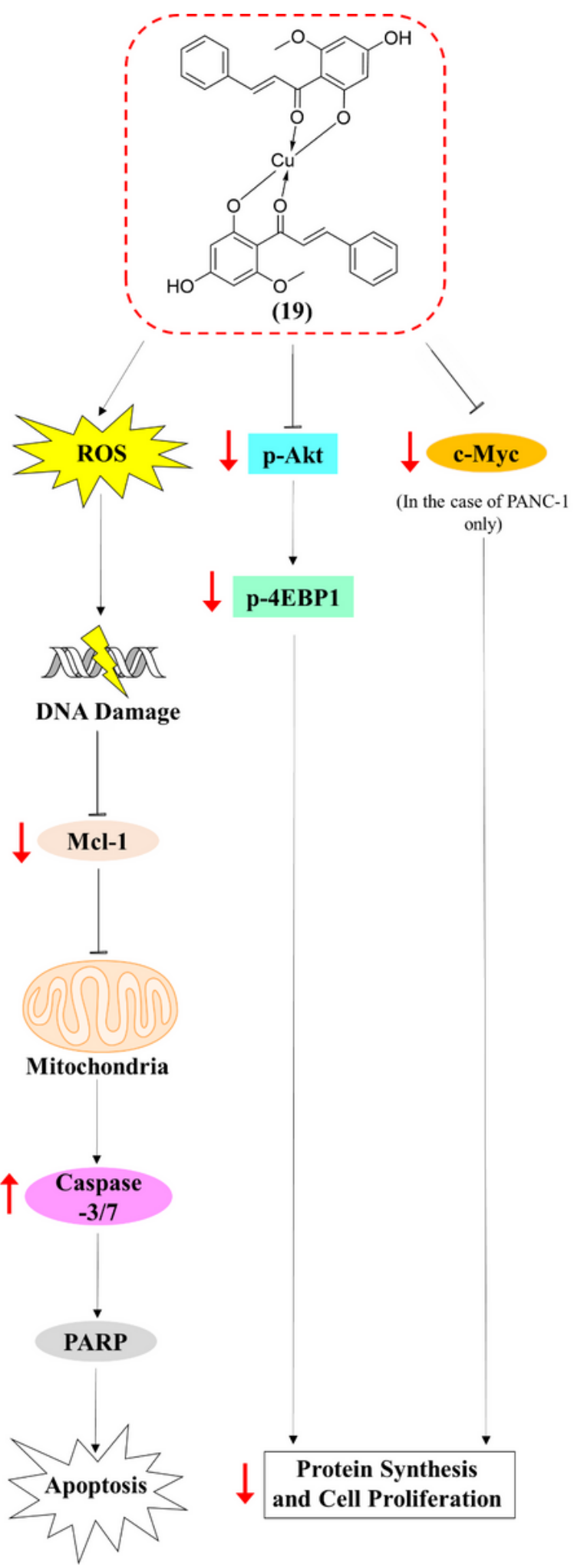

Figure 6

Schematic representation of the proposed signaling pathways perturbed by 19 in MDA-MB-468 and PANC-1 cells. 